\title{
Purification of a Chick Brain-Derived Growth Factor by Reversed-Phase High-Performance Liquid Chromatography
}

\author{
Robert Carlone, ${ }^{1}$ J. K. Kim, ${ }^{2}$ and Michel Rathbone ${ }^{2}$ \\ 'Department of Biological Sciences, Brock University, St. Catharines, Ontario L2S 3A1, Canada, and 'Department of \\ Neurosciences, McMaster University, Hamilton, Ontario L8N 3Z5, Canada
}

\begin{abstract}
A chick brain-derived growth factor (CBGF) has been purified to apparent homogeneity by a combination of ultrafiltration, DEAE ion-exchange, and reversed-phase high-performance liquid chromatography on $\mathrm{C}_{18}$ column. CBGF has an apparent molecular mass of approximately $1500 \mathrm{Da}$. The amino acid composition of CBGF has been determined and reveals a peptide containing predominantly glycine, glutamic acid/glutamine, and aspartic acid/asparagine. This mitogen is highly active, with half-maximal stimulation of chick brain astrocytes at $5 \mathrm{ng} / \mathrm{ml}$ in an assay using incorporation of methyl-3H-thymidine into DNA. In addition to its effects on chick astrocytes, purified CBGF from the $18 \mathrm{~d}$ chick embryo is mitogenic for amphibian limb regeneration blastema cells in vitro. A possible role for this mitogen in the nerve-dependent regeneration of amphibian appendages is discussed.
\end{abstract}

The nervous system is a rich source of several mitogenic factors for cells derived from the embryonic mesoderm, as well as for neurons and glia (Brockes and Lemke, 1981; Brockes, 1984; Bunge and Waksman, 1985; Carlone and Mescher, 1985). Many of these factors are proteins and peptides with a broad range of target specificities, some of which have been purified to homogeneity and sequenced (James and Bradshaw, 1984). We have previously isolated and partially purified a low-molecularweight peptide growth factor from adult chick brain, chick brainderived growth factor (CBGF) (Carlone and Rathbone, 1985). This factor is a mitogen for cultured regeneration blastemas from amputated regenerating newt limbs. It also promoted proliferation of serum-starved Swiss 3 T 3 cells. A similar mitogenic activity was detected in the brains of adult newts and of $18 \mathrm{~d}$ chick embryos.

We now report the purification to homogeneity, chemical characteristics, and amino acid composition of the CBGF.

\section{Materials and Methods}

Materials. Fertile white Leghorn eggs were obtained from Fleming Chicks Ltd. (Beamsville, Ontario). Adult newts ( $N$. viridescens viridescens) were obtained from Charles Sullivan (Nashville, TN). Insulin, sodium hydroselenite, progesterone, putrescine, human transferrin, phenylmethylsulfonyl fluoride, and crystalline BSA were purchased from Sigma

\footnotetext{
Received Oct. 1, 1986; revised Dec. 17, 1986; accepted Jan. 21, 1987.

We wish to thank Marilyn Ferracuti and Barbara Hamilton for typing the manuscript, Barbara Waters for her skilled assistance with astrocyte cultures, and Dr. Max Blum (Toronto) for performing the amino acid analysis. This work was supported by NSERC Grant A2802 and Grants from the Amyotrophic Lateral Sclerosis Society of Canada and the Cancer Research Society of Montreal.

Correspondence should be addressed to Dr. Robert Carlone at the above address.
}

Copyright $\odot 1987$ Society for Neuroscience $0270-6474 / 87 / 072163-05 \$ 02.00 / 0$
Chemical Company. Eagle's modified essential medium (MEM), Leibovitz's L-15, bovine achilles tendon collagen, and fetal bovine serum were from GIBCO. Tissue culture dishes and 24 well plates were from Falcon. DEAE 52 ion-exchange medium was obtained from Whatman. The $\mathrm{C}_{18} \mu$ Bondapak reversed-phase column was from Waters. Methyl${ }^{3} \mathrm{H}$-thymidine (specific activity, $40-60 \mathrm{Ci} / \mathrm{mmol}$ ) was obtained from Amersham Canada Ltd. All reagents were analytical grade.

Cell and tissue culture bioassays. Early to midcone stage (Iten and Bryant, 1973) regeneration blastemas from bilaterally denervated forelimbs of the newt were removed aseptically and cultured in $70 \%$ Leibovitz's L- 15 medium supplemented with $10 \%$ fetal bovine serum (FBS) and 0.14 units $/ \mathrm{ml}$ insulin (basal medium) for $48 \mathrm{hr}$ in 24 well test plates. Fractions to be tested for CBGF activity were then added to wells for $24 \mathrm{hr}$, followed by a $12 \mathrm{hr}$ labeling period with $0.5 \mu \mathrm{Ci} /$ well of methyl${ }^{3} \mathrm{H}$-thymidine. Contralateral control blastemas received fresh medium and label. Blastemas were washed, the wound epithelia removed, and mesenchymal tissues fixed in acid-alcohol. The tissues were then Feulgen-stained, squash preparations prepared, and slides processed for autoradiography.

Astroblasts used in bioassays for CBGF activity were prepared from $10 \mathrm{~d}$ chick embryo brains. Whole brains were dissected from decapitated 10-11 d chick embryos and the meninges removed. The brain tissue was dissociated by a combination of trypsinization and mechanical sieving through $63 \mu \mathrm{m}$ Nitex mesh and the non-neuronal cells selected by differential adhesion to collagen-coated petri dishes according to the methods of Hanson et al. (1982). The immunohistochemically defined astroblasts were maintained in Eagle's MEM supplemented with 33.3 mM D-glucose, $5 \mu \mathrm{g} / \mathrm{ml}$ insulin, $5 \mu \mathrm{g} / \mathrm{ml}$ human transferrin, $2 \times 10^{-8} \mathrm{M}$ progesterone, $100 \mu \mathrm{M}$ putrescine, and $3 \times 10^{-8} \mathrm{M}$ sodium selenite (basal medium) supplemented with $10 \%$ FBS. The cells for assay were harvested from stock dishes by trypsinization and seeded at a density of $3 \times 10^{4}$ cells/well in 24 well test plates. The cells were established in basal medium with $10 \%$ FBS for at least $48 \mathrm{hr}$, after which the medium was aspirated and replaced with basal medium without serum. After an additional $48 \mathrm{hr}$, the medium was replaced by basal medium $+1 \%$ FBS and varying concentrations of fractions to be tested. Control wells received fresh medium supplemented with either 1 or $10 \%$ FBS. The stimulation period lasted for $48 \mathrm{hr}$, with methyl- ${ }^{3} \mathrm{H}$-thymidine $(0.5 \mu \mathrm{Ci}$ / well) included in the assay wells for the last $24 \mathrm{hr}$. The cells were then washed, fixed in cold $10 \%$ TCA, air-dried, and solubilized in $0.5 \mathrm{ml}$ of $1 \%$ SDS in $0.3 \mathrm{~N} \mathrm{NaOH}$. TCA precipitable material was then filtered (Whatman, Type GF/A), dried, and counted in Aqueous Counting Solution (Amersham) in a Beckman scintillation counter (model LS 1800). CBGF activity was determined on at least 6 replicate wells in repeated assays and expressed as a percentage of control cultures receiving only basal medium $+10 \%$ FBS.

Purification of $C B G F$. The initial steps involved in the purification of CBGF from $18 \mathrm{~d}$ chick embryo brain include homogenization of the tissue in $0.01 \mathrm{M}$ sodium phosphate buffer $(\mathrm{pH} 7.4)$ containing $0.5 \mathrm{~mm}$ phenylmethylsulfonyl fluoride (PMSF) followed by ultracentrifugation and pressure ultrafiltration of the $100,000 \times g$ supernate through a series of Amicon Diaflo membranes of decreasing porosity (Types PM-30, YM-2, and UM-05) and are described in detail elsewhere (Carlone and Rathbone, 1985). The active material is retained and concentrated on the type UM-05 membrane (nominal molecular-weight cut-off, $\sim 1000$ ), dialyzed against $0.15 \mathrm{M}$ ammonium acetate on the same membrane, lyophilized, and stored at $-70^{\circ} \mathrm{C}$.

$D E A E$ ion-exchange chromatography. Whatman DE-52 was prepared 
Figure 1. Fractionation of $\mathrm{CBGF}$ activity on DEAE ion-exchange chromatography. Approximately $5 \mathrm{mg}$ UM05 retentate protein was applied to a DEAE 52 column and eluted with a linear gradient of $0.05-0.65 \mathrm{~m}$ ammonium acetate (pH 7.2) as described in Materials and Methods. CBGF activity eluted in a pooled series of fractions, $35 \mathrm{ml}$ (histogram) with 0.4-0.45 м ammonium acetate (dashed line). ${ }^{3} \mathrm{H}$-thymidine incorporation values represent a percentage of control values obtained with similar astrocyte cultures treated with $10 \%$ serum.

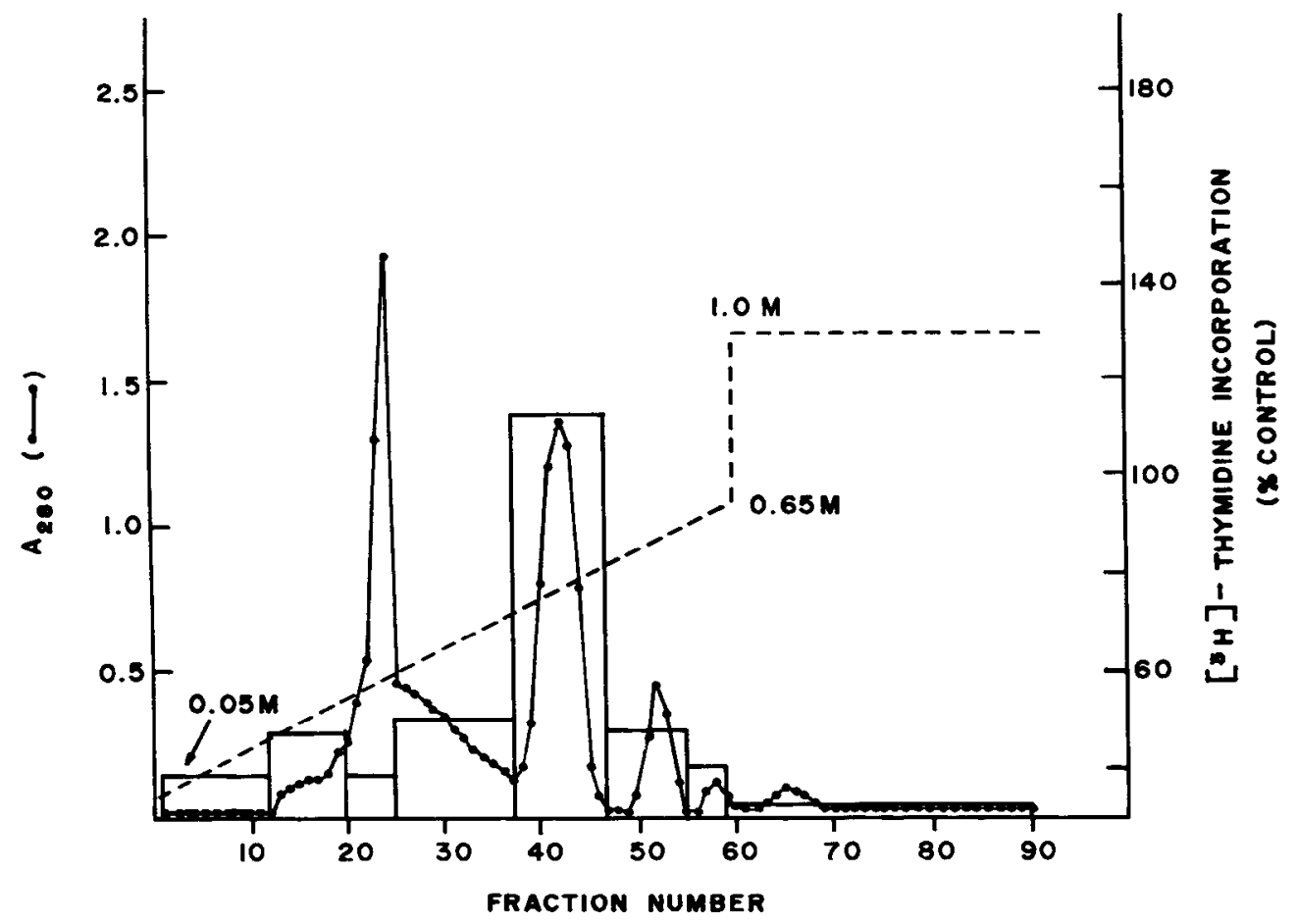

according to the manufacturer's instructions and equilibrated against $0.05 \mathrm{M}$ ammonium acetate. A $1.5 \times 30 \mathrm{~cm}$ column, containing approximately $40 \mathrm{ml}$ bed volume and eluted by gravity at a rate of $25 \mathrm{ml} /$ hr was prepared. The lyophilized UM-05 retentate material was reconstituted in equilibration buffer $(5 \mathrm{mg} / \mathrm{ml})$ and applied to the column. The loaded column was eluted with a linear gradicnt $(400 \mathrm{ml})$ of ammonium acetate $(0.05-0.65 \mathrm{M})$ at a flow rate of approximately $10 \mathrm{ml} /$ hr. Fractions, $3.5 \mathrm{ml}$, were collected, pooled, and lyophilized; CBGF activity was determined by bioassay.

Reversed-phase (RP) HPLC. Final purification was achieved on a Waters $\mu$ Bondapak $\mathrm{C}_{18}$ column $(3.9 \mathrm{~mm} \times 30 \mathrm{~cm})$. Fractionation of the active material from the DEAE column was carried out with a shallow gradient of $0-10 \%$ acetonitrile in $0.05 \%$ TFA during a $10 \mathrm{~min}$ period. The column eluant was monitored at either 212 or $280 \mathrm{~nm}$ (no differences were detected in the elution profile of equal portions of the same sample), and peaks were collected manually, evaporated to dryness, lyophilized, and stored frozen until assayed for CBGF activity.

Amino acid analysis. Active fractions from the HPLC column were dried under vacuum and placed in a $40 \mathrm{ml}$ vial containing $1 \mathrm{ml}$ of a mixture of $\mathrm{HCl}$ : TFA : $\mathrm{H}_{2} \mathrm{O}(6: 2: 3, \mathrm{vol} / \mathrm{vol})$ and $100 \mu \mathrm{l}$ of mcrcaptoacetic acid. The vial was purged with argon, sealed, and placed in a $165^{\circ} \mathrm{C}$ oven for $30 \mathrm{~min}$. After cooling, the tubes were dried under vacuum and the hydrolysate reconstituted with $50 \mu 1 \mathrm{H}_{2} \mathrm{O}$. Following derivatization, the PTH-amino acids were analyzed on an automated amino acid analyzer (Applied Biosystems model 120A).

\section{Results}

$D E A E$ ion-exchange chromatography of the UM-05 retentate fraction

The elution profile and biological activity distribution after DEAE ion-exchange chromatography of the UM-05 retentate fraction is shown in Figure 1. Most of the biologically active material elutes in one peak (fractions 38-47) at approximately $0.45 \mathrm{M}$ ammonium acetate. This active fraction at $50 \mathrm{ng} / \mathrm{ml}$ was roughly $10 \%$ more stimulatory to quiescent chick embryo astroblasts than was the addition of fresh basal medium containing $10 \%$ FBS and resulted in a 6- to 7 -fold increase in ${ }^{3} \mathrm{H}$-thymidine incorporation compared with the addition of basal medium supplied with 1\% FBS (Table 1). As can be seen in Table 2, an approximately 18 -fold purification was achieved by this chro- matographic step. The material in tubes $38-47$ was pooled, lyophilized after concentration, and further fractionated on an RP-HPLC column.

\section{Reversed-phase HPLC separation of the DEAE fraction with $C B G F$ activity}

The protein distribution and growth-promoting activity of the fraction obtained by DEAE ion-exchange chromatography was further analyzed by submitting it to reversed-phase HPLC on a $\mathrm{C}_{18} \mu$ Bondapak column. As shown in Figure 2, when 5-10 $\mu \mathrm{g}$ of protein was processed in this way, significant heterogeneity was apparent in the DEAE fraction. At least 4 UV-absorbing peaks could be distinguished and separated. UV-absorbing peaks were collected manually, evaporated, lyophilized, and assayed for activity on the chick astroblasts. The major peak, eluting at approximately $5 \%$ acetonitrile, contained all of the recoverable CBGF activity (Table 1) and represented a 12.5-fold further purification of the mitogenic activity from the DEAE cellulose52 fraction (Table 2). Repeated chromatography of this active material on the same column under different elution conditions resulted in an apparently homogenous single peak with biological activity. midine incorporation in cultured astrocytes is shown in Figure 3. Half-maximal and maximal stimulation of division in these cells occurred at CBGF concentrations of approximately $5 \mathrm{ng} /$ $\mathrm{ml}(\sim 3 \mathrm{nM})$ and $10 \mathrm{ng} / \mathrm{ml}(\sim 6 \mathrm{nM})$, respectively.

\section{Amino acid analysis of HPLC purified CBGF}

The amino acid composition of CBGF eluted from the RPHPLC column and rechromatographed on the same column is given in Table 3. Based on an estimated molecular weight of approximately 1500-2000 Da (Carlone and Rathbone, 1985) and extrapolating to the nearest integer for each determination, CBGF appears to be a small polar peptide, containing predominantly Gly, Glu/Gln, and Asp/Asn.
A typical dose response of HPLC-purified CBGF on ${ }^{3} \mathrm{H}$-thy- 


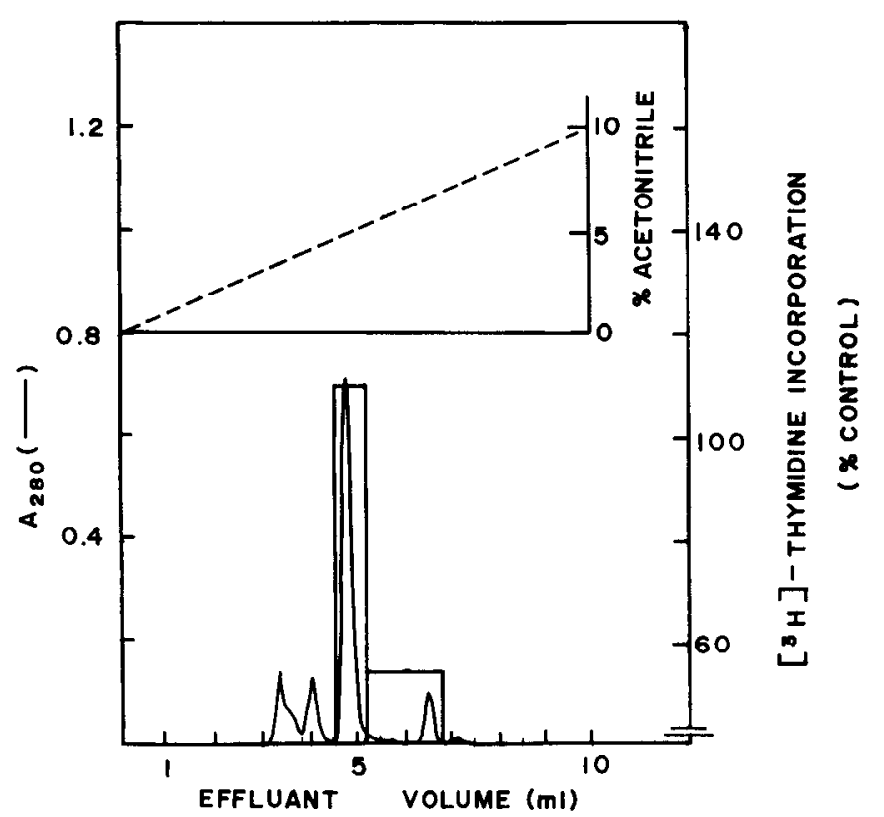

Figure 2. RP-HPLC fractionation of CBGF activity. CBGF activity recovered from the DEAE 52 column was concentrated, lyophilized, and chromatographed on $\mathrm{a}_{18} \mu$ Bondapak column as described under Materials and Methods. The majority of the recoverable CBGF activity elutes as a single, prominent peak (histogram).

\section{Effect of RP-HPLC purified CBGF on cultured blastemas from} the regenerating limb of the newt

In a previous study (Carlone and Rathbone, 1985), partially purified CBGF from adult chicken brain was shown to be mitogenic for cultured limb blastemas explanted from the regenerating forelimbs of the adult newt, Notophthalmus viridescens. It was of interest to determine whether the more highly purified factor from chick embryo brain was mitogenic for cultured regenerates from the amphibian limb. As can be seen from Table 4, CBGF activity purified by RP-HPLC is mitogenic for cultured newt limb blastemas when tested at $10 \mathrm{ng} / \mathrm{ml}$. Treatment resulted in an average 3.6-fold increase in the percentage of labeled blastema nuclei.

\section{Discussion}

A low-molecular-weight peptide growth factor, CBGF, from embryonic chick brain has been purified to apparent homogeneity using DEAE ion-exchange chromatography and RP-HPLC. CBGF has a high specific mitogenic activity on cultured astrocytes from the $10 \mathrm{~d}$ chick embryo brain, as well as on cultured regeneration blastemas from the forelimbs of adult newts. Halfmaximal stimulation $\left(\mathrm{ED}_{50}\right)$ of ${ }^{3} \mathrm{H}$-thymidine incorporation into cultured chick embryo astrocytes occurs at a concentration of approximately $3 \mathrm{~nm}$ CBGF. This value is comparable to values exhibited by other purified growth factors and neural peptides such as platelet-derived growth factor $\left(\mathrm{ED}_{50}=1 \mathrm{ng} / \mathrm{ml}\right.$; Raines and Ross, 1985) and bombesin $\left(\mathrm{ED}_{50}=1 \mathrm{~nm}\right.$; Rozengurt and Sinnet-Smith, 1983) and indicates that CBGF acts in a "physiologically relevant" concentration range.

A number of other cell types have been tested for their response to CBGF-including chick embryo myoblasts, meningeal fibroblasts, and neuroblasts and mouse embryo fibroblasts (both primary cultures and established lines)-and have been found to be unresponsive at all concentrations tested (Carlone
Table 1. Fractionation of CBGF activity

\begin{tabular}{lc} 
Fraction tested & $\begin{array}{l}{ }^{3} \text { H-thymidine } \\
\text { incorporation } \\
(\times \mathrm{cpm} / \text { well }) \pm \mathrm{SD}\end{array}$ \\
\hline Defined medium (DM) & $5270 \pm 621$ \\
DM $+1 \%$ FBS & $10,000 \pm 3045$ \\
DM $+10 \%$ FBS & $26,060 \pm 5365$ \\
DEAE 52 (pooled, fraction 4) & ${ }^{a}$ \\
HPLC (fraction 3) & $36,645 \pm 2487$ \\
\end{tabular}

Effects of chromatographic fractions on ${ }^{3} \mathrm{H}$-thymidine incorporation in astrocyte cultures from the $10 \mathrm{~d}$ chick embryo. Values represent the means \pm SD for at least 6 replicate cultures for each treatment. Fractions were added to the defined medium supplemented with $1 \%$ fetal bovine serum (FBS) in all cases. Concentrations tested were DEAE 52, $100 \mathrm{ng} / \mathrm{ml}$; HPLC, $10 \mathrm{ng} / \mathrm{ml}$.

a See Figure 1.

${ }^{b}$ See Figure 2.

et al., 1987). The spectrum of cell types affected by CBGF in vitro is somewhat limited and parallels (with one significant exception) the spectrum of cells stimulated by glial growth factor (GGF), a 31,000 Da protein isolated from bovine brain and pituitary (Lemke and Brockes, 1984). As well as being mitogenic for astrocytes (Brockes et al., 1980) and fibroblasts (Brockes and Lemke, 1981), the distinguishing feature of GGF is its mitogenicity on the cultured rat Schwann cell, a cell type normally unresponsive to a variety of purified growth factors (Salzer et al., 1980). We have not yet determined whether CBGF is mitogenic to cultured Schwann cells of the rat.

CBGF appears to be unlike any of the limited number of purified and well-characterized peptide growth factors. The mass and amino acid composition distinguish it from GGF, $M_{r}=$ 31,000 (Lcmkc and Brockes, 1984); murine epidermal growth factor, 6045 (Taylor et al., 1972); human insulin-like growth factors I and II, 7649 and 7471, respectively (Rinderknecht and Humbel, 1978a, b); platelet-derived growth factor, 28-32,000 (Deuel et al., 1981; Raines and Ross, 1982); both acidic and basic fibroblast growth factors from brain, 16,600 and 16,000, respectively (Gospodarowicz et al., 1978; Thomas et al., 1984); and a human T-lymphocyle-derived glial growth promoting activity (GGPF), 30,000 (Benveniste et al., 1985).

Recently, interest has arisen in the concept of neuropeptides as mitogens, a previously unsuspected role for these neural factors (Rozengurt et al., 1979; Globus et al., 1983; Rozengurt and Sinnet-Smith, 1983; Nilsson et al., 1985). Because of its small size, it is possible that CBGF is more closely related to neuro-

\begin{tabular}{|c|c|c|c|c|}
\hline Step & $\begin{array}{l}\text { Total } \\
\text { protein } \\
(\mathrm{mg})\end{array}$ & $\begin{array}{l}\mathrm{ED}_{50}{ }^{a} \\
(\mathrm{ng})\end{array}$ & $\begin{array}{l}\text { Purifi- } \\
\text { cation } \\
\text { factor } \\
\text { (fold) }\end{array}$ & $\begin{array}{l}\text { Yield } \\
(\% \\
\text { initial }) \\
\end{array}$ \\
\hline $105,000 \times g$ supernatant & 23,800 & 125,000 & - & 100.0 \\
\hline UM-05 filter retentate & 4.6 & 450 & 278 & 43.0 \\
\hline DEAE cellulose 52 & 0.18 & 25 & 5000 & 30.3 \\
\hline $\mathrm{C}_{18} \mathrm{HPLC}$ & 0.02 & 5 & 62,500 & 16.8 \\
\hline
\end{tabular}

The activity was purified from 240 fresh $18 \mathrm{~d}$ chick embryo brains as described in the text.

" $\mathrm{ED}_{50}$ is the amount of a given fraction required to give half-maximal stimulation of ${ }^{3} \mathrm{H}$-thymidine incorporation in the astrocyte cell assay described in the text and as illustrated in Figure 3. 
Figure 3. Dose response of HPLCpurified CBGF on ${ }^{3} \mathrm{H}$-thymidine incorporation in cultured chick embryo astrocytes. Data points are means $\pm \mathrm{SD}$ for 3 determinations. Bioassays are performed in 24 well culture plates as described under Materials and Methods. Control cultures $(0 \mathrm{ng} / \mathrm{ml}$ CBGF) received only fresh medium.

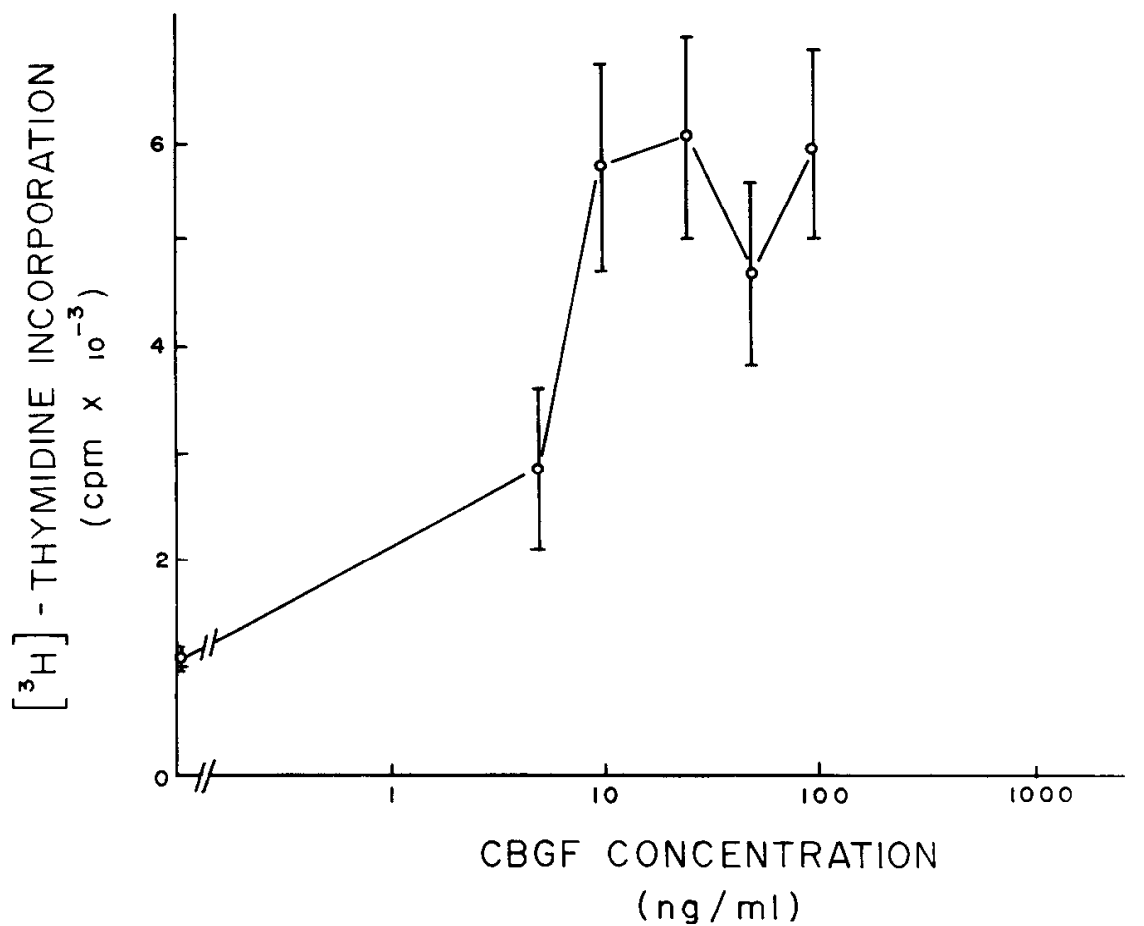

Despite the increasing number of growth factors purified from a variety of tissue sources, it has been difficult in most cases to determine their precise role in vivo in specific developmental and regenerative processes. The epimorphic regeneration of the amphibian limb, however, represents a system whereby a more rigorous assessment of the mechanisms underlying the control of cell division by growth factors in vivo is possible. In this system, the proliferation of a well-defined population of undifferentiated cells, the blastema, has been shown to be dependent upon a growth factor (or factors) produced by a single, identified heterologous tissue source, the peripheral nerves in the limb stump (Singer, 1978; Carlone and Mescher, 1985; Brockes and Kintner, 1986). Although a number of candidates have been proposed-including fibroblast growth factor (Gospodarowicz and Mescher, 1980), substance P (Globus et al., 1983), glial growth factor (Brockes and Kintner, 1986), and transferrin (Mescher and Munaim, 1984) - the identity of this neurotrophic growth factor remains unknown. The present results would sup-

Table 4. Effect of CBGF on proliferation of newt limb blastema cells in vitro

\% Labeled mesenchymal nuclei ${ }^{a}$

\begin{tabular}{llll} 
& \multicolumn{3}{l}{ \% Labeled mesenchymal nuclei ${ }^{\alpha}$} \\
\cline { 2 - 4 } Animal & Control & CBGF-treated & \\
\hline 1 & 1.48 & 5.18 & 3.5 \\
2 & 0.76 & 3.61 & 4.8 \\
3 & 1.56 & 4.64 & 3.0 \\
4 & 0.74 & 5.51 & 7.5 \\
5 & 3.28 & 5.34 & 1.6 \\
6 & 3.89 & 5.27 & 1.4
\end{tabular}

a Bud stage contralateral blastemas from each animal were cxcised $72 \mathrm{hr}$ after bilateral surgical resection of the brachial plexi of each animal and cultured as described under Materials and Methods. The values represent percentages of labeled blastema cell nuclei in autoradiographs of mesenchymal squash preparations. More than 1000 nuclei were counted for each determination.

${ }^{b} \mathrm{CBGF}$ was added to cultures at $10 \mathrm{ng} / \mathrm{ml}$. 
port a role for CBGF (or a CBGF-likc factor from amphibian neural tissue) in the nerve-dependent stimulation of blastema cell proliferation. Purified CBGF was shown to be mitogenic for blastema cells at physiologically relevant concentrations (10 $\mathrm{ng} / \mathrm{ml})$. In addition, in preliminary studies, fractionation of crude adult newt brain homogenates by ultrafiltration, and DEAE cellulose ion-exchange chromatography have revealed a blastema mitogen with biochemical characteristics identical to embryonic chick CBGF (data not shown). Studies are presently underway to determine whether CBGF stimulates proliferation of an identifiable subpopulation of blastema cells whose division has been shown to depend upon the action of peripheral nerve (Kintner and Brockes, 1985).

\section{References}

Benveniste, E. N., J. E. Merril, S. E. Kaufman, D. W. Golde, and J. C. Gasson (1985) Purification and characterization of a human T-lymphocyte-derived glial growth-promoting factor. Proc. Natl. Acad. Sci. USA 82: 3930-3934.

Brockes, J. P. (1984) Mitogenic growth factors and nerve dependence on limb regeneration. Science 225: 1280-1287.

Brockes, J. P., and G. E. Lemke (1981) The neuron as a source of mitogen. In Development in the Nervous System, D. R. Garrod and J. D. Feldman, eds., pp. 309-327, Cambridge U. P., Cambridgc, UK.

Brockes, J. P., G. E. Lemke, and D. R. Balzer (1980) Purification and preliminary characterization of a glial growth factor from the bovine pituitary. J. Biol. Chem. 255: 8374-8377.

Brockes, J. P., and C. R. Kintner (1986) Glial growth factor and nervedependent proliferation in the regeneration blastema of urodele amphibians. Cell 45: 301-306.

Bunge, R. P., and B. H. Waksman (1985) Glial development and interactions. Trends Neurosci. 8: 424-427.

Carlone, R. L., and A. L. Mescher (1985) Trophic factors from nerves. In Regulation of Vertebrate Limb Regeneration, R. E. Sicard, ed., pp. 93-105, Oxford U. P., New York.

Carlone, R. L., and M. P. Rathbone (1985) Partial purification of a low-molecular-weight growth factor from chicken brain. J. Cell Physiol. 124: 467-473.

Deuel, T., J. S. Huang, R. T. Proffitt, J. V. Baenziger, D. Chang, and B. B. Kennedy (1981) Human platelet-derived growth factor: Purification and resolution into two active protein fractions. J. Biol. Chem. 256: 8896-8899.

Globus, M., S. Vethamany-Globus, A. Kesich, and G. Milton (1983) Roles of neural peptide substance $\mathrm{P}$ and calcium in blastema cell proliferation in the newt, Notophthalmus viridescens. In Limb Development and Regeneration (Part A), J. F. Fallon and A. I. Caplan, eds., pp. 513-524. Alan R. Liss, New York.

Gospodarowicz, D., and A. L. Mescher (1980) Fibroblast growth factor and the control of vertebrate regeneration and repair. Ann. NY Acad. Sci. 339: 151-174.

Gospodariwicz, D., H. Bialecki, and G. Greenburg (1978) Purification of the fibroblast growth factor activity from bovine brain. J. Biol. Chem. 253: 3736-3743.

Hanson, G. R., P. L. Iversen, and L. M. Partlow (1982) Preparation and partial characterization of highly purified primary cultures of neurons and non-neuronal (glial) cells from embryonic chick cerebral hemispheres and several other regions of the nervous system. Dev. Brain Res. 3: 529-545.

Iten, L. E., and S. V. Bryant (1973) Forelimb regeneration from different levels of amputation in the newt, Notophthalmus viridescens: Length, rate and stages. W. Roux. Arch. 173:263-282.

James, R., and R. A. Bradshaw (1984) Polypeptide growth factors. Annu. Rev. Biochem. 53: 259-292.

Kintner, C. R., and J. P. Brockes (1985) Monoclonal antibodies to the cells of a regenerating limb. J. Embryol. Exp. Morphol. 89: 3755.

Lemke, G. E., and J. P. Brockes (1984) Identification and purification of glial growth factor. J. Neurosci. 4: 75-83.

Mescher, A. L., and S. I. Munaim (1984) "Trophic" effect of transferrin on amphibian limb regeneration blastemas. J. Exp. Zool. 230: 485490

Nilsson, J., A. M. von Euler, and C.-J. Dalsgaard (1985) Stimulation of connective tissue cell growth by substance $\mathrm{P}$ and substance $\mathrm{K}$. Nature 315: 61-63.

Raines, E. W., and R. Ross (1982) Platelet-derived growth factor. 1. High yield purification and evidence for multiple forms. J. Biol. Chem. 257: 5154-5160.

Raines, E. W., and R. Ross (1985) Purification of human plateletderived growth factor. Methods Enzymol. 109: 749-773.

Rinderknecht, E., and R. E. Humbel (1978a) The amino acid sequence of human insulin-like growth factor I and its structural homology with proinsulin. J. Biol. Chem. 253: 2769-2776.

Rinderknecht, E., and R. E. Humbel (1978b) Primary structure of human insulin-like growth factor II. FEBS Lett. 89: 283-286.

Rozengurt, E., and J. Sinnet-Smith (1983) Bombesin stimulation of DNA synthesis and cell division in cultures of Swiss 3 T3 cells. Proc. Natl. Acad. Sci. USA 80: 2936-2940.

Rozengurt, E., A. Legg, and P. Pettican (1979) Vasopressin stimulation of mouse 3T3 cell growth. Proc. Natl. Acad. Sci. USA 76: 1284-1287.

Salzer, J. L., A. K. Williams, L. Glaser, and R. P. Bunge (1980) Studies of Schwann cell proliferation. II. Characterization of the stimulation and specificity of the response to a neurite membrane fraction. J. Cell Biol. 84: 753-756.

Singer, M. (1978) On the nature of neurotrophic phenomenon in urodele limb regeneration. Am. Zool. 18: 829-841.

Taylor, J. M., W. M. Mitchell, and S. Cohen (1972) Epidermal growth factor. Physical and chemical properties. J. Biol. Chem. 247: 59285934.

Thomas, K. A., M. Rios-Candelore, and S. Fitzpatrick (1984) Purification and characterization of acidic fibroblast growth factor from bovine brain. Proc. Natl. Acad. Sci. USA 81: 357-361. 